\title{
MINIREVIEW
}

\section{One Hundred Years of Virology}

\author{
ALICE LUSTIG AND ARNOLD J. LEVINE* \\ Department of Molecular Biology, Lewis Thomas Laboratory, \\ Princeton University, Princeton, New Jersey 08544-1014
}

One hundred years ago a young Russian scientist, Dimitri Ivanovsky (1864 to 1920), presented a paper before the Academy of Sciences of St. Petersburg in which he stated that "the sap of leaves infected with tobacco mosaic disease retains its infectious properties even after filtration through Chamberland filter candles" (10). This observation suggested a disease agent smaller than any known before and was the first step in a long series of observations and experiments that led to the discovery of viruses.

While it is often difficult to assign a single date to the discovery of viruses, Ivanovsky is generally given credit for first recognizing an entity that is filterable and submicroscopic in size that might well be the cause of a disease. Indeed, the term filterable agent was the name used to describe these organisms well before the term viruses was specifically applied to them. Filtration became an experimental definition. Ivanovsky's contributions and priority for the discovery were "willingly acknowledged" by Martinus Beijerinck who, unaware of Ivanovsky's work, published similar findings 6 years later in 1898 (3). Fifty years later, in 1944, Wendell Stanley writing in Science stated that "there is considerable justification for regarding Ivanovsky as the father of the new science of Virology" (17).

The nineteenth century saw the final defeat of the concept favoring spontaneous generation of organisms and an acceptance of the germ theory of disease. The new definition of causality for a disease inherent in Robert Koch's postulates and the proof that anthrax in cattle was caused by Bacillus anthraxus had a powerful impact on the scientists working in the last decades of the nineteenth century. Although some, like the great anatomist Jacob Henle (a teacher of Robert Koch and grandfather of Werner Henle), had the imagination to conceive of infectious agents with the properties of viruses as early as 1840 , these ideas failed to gain acceptance for a lack of experimental evidence. The path to that evidence begins with three scientists independently working on the tobacco mosaic disease, Adolf Mayer, Dimitri Ivanovsky, and Martinus Beijerinck (Fig. 1).

Dimitri Ivanovsky, son of a landowner in Kherson Guberniya, was born in the village of Nix near St. Petersburg on 28 October 1864. After the death of his father when Ivanovsky and his siblings were still young, the family moved to a poor section of St. Petersburg. There Ivanovsky attended secondary school and served as a tutor to supplement his mother's pension. Ivanovsky was educated at the gymnasium of Gdov and at St. Petersburg, graduating as a gold medalist in the spring of 1883. After defending his thesis "On Two Diseases of Tobacco Plants," Ivanovsky was awarded the degree of candidate of science in 1888 by St.

* Corresponding author.
Petersburg University. He stayed on at the University to prepare for a career in academic teaching and to work in the botanical laboratory. Later he accepted an assistantship at the Academy of Sciences in the laboratory of Andrei Famintsyn, one of the first Russian botanists to specialize in plant physiology. Ivanovsky was awarded a master's degree in 1895 for his dissertation "An Investigation into the Fermentation of Alcohol," and a doctorate was awarded in 1903 for his work on the tobacco mosaic virus (TMV).

While still a student at the University of St. Petersburg, Ivanovsky was commissioned in 1887 and again in 1890 by the Russian Department of Agriculture to investigate the causes of a disease which had struck the tobacco plantations in Bessarabia, Ukraine, and the Crimea. Ivanovsky began his studies on the tobacco diseases, building on the previous work of Adolf Mayer, a German chemist who was the first scientist to do microbiological research on tobacco mosaic disease. Mayer had begun his research on diseases of tobacco in Holland in 1879. Although Mayer did not discover tobacco mosaic disease, he was the first to give it a permanent name (after the mosaic of dark and light spots on infected leaves) and is generally credited with proving the infectious nature of the disease. Mayer's experiment of inoculating healthy plants with the juice extracted by grinding up leaves from diseased plants was the first experimental transmission of a viral disease in plants. Without knowing the causal agent, which he was unable to see or culture, he reported ". . . I suddenly made the discovery that the juice from diseased plants obtained by grinding was a certain infectious substance for healthy plants . . . in nine cases out of ten (of inoculated plants) one will be successful in making the healthy plant ... heavily diseased" (14). These studies established the infectious nature of this disease, but neither bacterial nor fungal agents could be cultured or detected and so Koch's postulates could not be employed. Mayer preferred to conclude that the disease could be caused by bacteria whose nature prevented their isolation and this would be revealed in future studies.

After his return from the Crimea where he studied the tobacco mosaic disease, Ivanovsky came to an interesting conclusion about the etiologic agent of this disease. In a paper read on 12 February 1892 before the Academy of Sciences in St. Petersburg, Ivanovsky reported that the tobacco mosaic disease was caused by a filterable infectious agent (10). He passed infected sap through what was then considered to be a bacteria-proof Chamberland filter made from unglazed porcelain. The Chamberland filter, perfected in 1884 by Charles Chamberland, one of Pasteur's collaborators, had become a common instrument of bacteriological research, because it was assumed that the pores of the filter were small enough to hold back the majority of bacteria. After inoculating the filtrate into healthy plants, Ivanovsky 


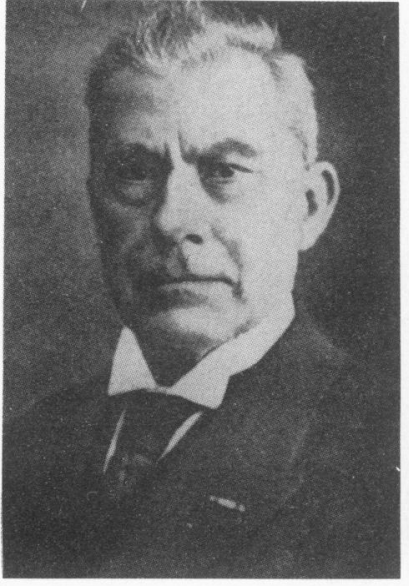

MARTINUS WILLEM BEIJERINCK

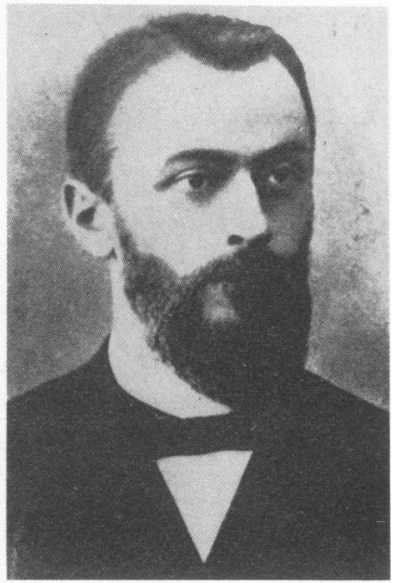

DMITRII IVANOVSKY

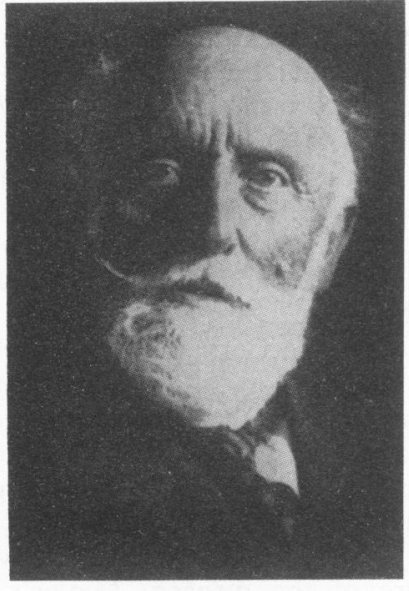

ADOLF MAYER

FIG. 1. Pioneers in virus research.

observed that the filtrate remained unchanged and reproduced the disease. He concluded that the filtrate might contain an infectious agent. It was this filtration experiment that was the first step in the discovery of viruses. Ivanovsky, like Mayer before him, tried to interpret his observations in the light of the germ theory of disease and Koch's postulates, even suggesting that his unusual results might be due to a defect in the filter candle or to his experimental method. It is not surprising that Ivanovsky failed to understand the full significance of his filtration experiments, for his results were directly contrary to all accepted scientific knowledge. $\mathrm{He}$ even believed for a period of time that his experiment should be interpreted as detecting a bacterial toxin which, as a soluble substance, would pass through the Chamberland filter. However, after learning of the work of Martinus Beijerinck who demonstrated that the filterable agent could reproduce itself, Ivanovsky accepted the idea of a filterable infectious agent.

The last and most detailed study on tobacco mosaic disease undertaken by Ivanovsky was published in 1903 (11). In this work Ivanovsky described abnormal intracellular inclusion bodies in the host cells of virus-diseased plants, and his descriptions of crystallike bodies are now clearly believed to be of the virus itself. Although he did not recognize his inclusion bodies as the virus, Ivanovsky did argue for the existence of a connection between the crystals and the pathogenic source and presented evidence that this pathogenic agent could replicate only in living organisms.

Independently of Ivanovsky, Martinus Beijerinck, the third major scientist studying tobacco mosaic disease in the last decade of the nineteenth century, found in 1898 that this causal agent was indeed filterable. He extended the studies and experiments on tobacco mosaic disease beyond anything Ivanovsky had accomplished and determined that the infectious agent was able to multiply within living plants, hypothesized that it was liquid and soluble, and described it as a "contagium vivum fluidum" (contagious living fluid) (14). This concept began a 25 -year debate about the nature of viruses, liquids or particulate? A debate which was laid to rest with d'Herelle's plaque assay in 1917 (6) and the first electron micrographs of TMV in 1939 (12).

Beijerinck, like Ivanovsky, was influenced by Mayer and was a collaborator of his at the Agricultural School of Wageningen. Beijerinck examined the infectious filtrates under the light microscope and tried to detect the causal bacteria. Like Mayer and Ivanovsky before him, he at first attributed his inability to detect or to culture the agent to the state of current microbiological techniques and not to properties of the agent itself. Although he was not aware of Ivanovsky's previous discoveries, Beijerinck reported that "sap from infected plants, after having traversed a porcelain filter, remains virulent" (3). He found that the mosaic disease had the ability to multiply (with dilution, it returned to its original strength) within living plants, suggesting to him that the pathogen was not a chemical substance but replicated through serial passages. He also observed that there was no sign of replication outside the plant and that only growing parts of the tobacco plant became infected; the pathogen multiplied only in tissues undergoing cell division.

Thus, TMV played a key role in the origins of virology. In a small series of steps from Mayer to Ivanovsky to Beijerinck, the concept of a filterable agent, too small to observe in the light microscope but able to cause disease by multiplying in living cells and tissue, was born. Loeffler and Frosch rapidly (1898) described and isolated the first filterable agent from animals, the foot-and-mouth disease virus (13), and Walter Reed and his team (1901) recognized the first human virus, yellow fever virus (15). By the start of the twentieth century, the concept of viruses was firmly established.

It is interesting to note that TMV continued to play a key role in conceptual advances in virology throughout the twentieth century. Beginning as early as 1929 , Vinson and Petre (18) could precipitate the virus by adding selected salts to the infectious filtrates. The treatment of viruses as chemical entities was in itself a conceptual advance. The crystalization of TMV by Wendell Stanley in 1935 (16) brought the infectious agent into the world of the chemists, and the clear demonstrations of protein and RNA components of TMV by Bawden and Pirie in $1936(1,2)$ were followed by the first "visualization" of a virus by X-ray crystallography (4). The rods of constant diameter aligned in a hexagonal array contained RNA and protein, and this was the earliest view of a virus along with the first electron micrographs in Germany in 1939 (12). The genome of TMV was first used in 1956 to prove that infectious or genetic information could be stored in RNA molecules $(8,9)$, and the concept of self-assembly with an infectious virus was pioneered by using TMV RNA and coat protein (5). The relationship between the genetic information and its protein sequences as well as a confirmation of the universality of the genetic code both owe a great 
deal to TMV research efforts in the 1960s and 1970s (7). Along with the extraordinary research efforts with bacteriophages and animal viruses, the field of virology has contributed to all phases of the life sciences with new and important concepts.

Ivanovsky died on 20 June 1920 in Ukraine. During his forced evacuation in World War I from the University of Warsaw where he held the chair in plant anatomy and physiology, he lost his laboratory notebooks, his library, and equipment. Although he may not have properly evaluated the consequences of his discovery and during his lifetime was not given the full recognition he may have deserved, the field of virology that he fathered stands testimony to his scientific achievements. In honor of Ivanovsky's work, the USSR established the D. I. Ivanovsky Institute of Virology in Moscow and the Academy of Medical Sciences each year awards the D. I. Ivanovsky prize for the year's best work in virology.

We look forward to the next 100 years of virus research.

\section{REFERENCES}

1. Bawden, F. C., and N. W. Pirie. 1937. The isolation and some properties of liquid crystalline substances from solanaceous plants infected with three strains of tobacco mosaic virus. Proc. R. Soc. Lond. Ser. B Biol. Sci. 123:274.

2. Bawden, F. C., N. W. Pirie, J. D. Bernal, and I. Fankuchen. 1936. Liquid crystalline substances from virus infected plants. Nature (London) 138:1051.

3. Beijerinck, M. W. 1898. Concerning a contagium vivum fluidum as a cause of the spot-disease of tobacco leaves. Verh. Akad. Wet. Amsterdam II(6):3-21.

4. Bernal, J. D., and I. Fankuchen. 1941. X-ray and crystallo- graphic studies of plant virus preparations. J. Gen. Physiol. 25:147.

5. Butler, P. J. G., and A. Klug. 1971. Assembly of the particle of TMV from RNA and disk of protein. Nature (London) New Biol. 229:47.

6. d'Herelle, F. H. 1917. Sur un microbe invisible antagoniste des bacilles dysentériques. C.R. Acad. Sci. 165:373-375.

7. Fraenkel-Conrat, H., and B. Singer. 1972. The chemical basis for the mutagenicity of hydroxylamine and methoxyamine. Biochim. Biophys. Acta 262:264.

8. Fraenkel-Conrat, H., B. Singer, and R. C. Williams. 1957. Infectivity of viral nucleic acid. Biochim. Biophys. Acta 25:87.

9. Gierer, A., and G. Schramm. 1956. Die infektiosität der ribonukleinsäure des tabakmosaikvirus. Z. Naturforsch. Teil B 11:138.

10. Ivanovsky, D. 1882. Concerning the mosaic disease of the tobacco plant. St. Petsb. Acad. Imp. Sci. Bul. 35:67-70.

11. Ivanovsky, D. 1903. On the mosaic disease of tobacco. Z. Pflanzenkr. Pflanzenpathol. Pflanzenschutz 13:1-41.

12. Kausche, G. A., and H. Ruska. 1939. Die Struktur dur "kristallinen Aggregate" des Tabakmosaikvirus-proteins. Biochem. Z. 303:211.

13. Loeffler, F., and P. Frosch. 1898. Zentralbl. Bakteriol. Parasitenkd. Infektionskr. Hyg. Abt. 1 Orig. 28:371.

14. Mayer, A. 1886. Concerning the mosaic disease of tobacco. Landivertschaftlichen Versuchs-Stationen 32:451-567.

15. Reed, W., J. Carroll, A. Agramonte, and J. Lazear. 1991. Senate documents. 66(822):156.

16. Stanley, W. 1935. Isolation of a crystaline protein possessing the properties of tobacco-mosaic virus. Science 81:644-645.

17. Stanley, W. M. 1944. Soviet studies on viruses. Science 99:136138.

18. Vinson, C. G., and A. W. Petre. 1929. Mosaic disease of tobacco. Bot. Gaz. 87:14. 